\title{
Analysis of the Influence of Financial Flexibility on Enterprises
}

\author{
Xiangyu Xie, Jiawen Zhao \\ School of Business, University of Hohai, Nanjing, China \\ Email: Xie_xiangyu1823@163.com
}

How to cite this paper: Xie, X. Y., \& Zhao, J. W. (2020). Analysis of the Influence of Financial Flexibility on Enterprises. Open Journal of Business and Management, 8 , 1917-1922.

https://doi.org/10.4236/ojbm.2020.84117

Received: May 27, 2020

Accepted: July 28, 2020

Published: July 31, 2020

Copyright $\odot 2020$ by author(s) and Scientific Research Publishing Inc. This work is licensed under the Creative Commons Attribution International License (CC BY 4.0).

http://creativecommons.org/licenses/by/4.0/

(c) (i) Open Access

\begin{abstract}
Through the analysis of empirical papers on financial flexibility over the years it can find that the impact of financial flexibility on corporate value shows a trend of increasing first and then decreasing, and there is an inflection point. Financial flexibility reserve is helpful to reduce the credit risk of the enterprise and help the enterprise to buffer under the environment of greater uncertainty. This buffer is more obvious when the financing constraint is greater. At the same time, this paper puts forward relevant suggestions on how to improve the financial flexibility of enterprises: increase the proportion of equity funds, increase capital reserves, and choose appropriate dividend policies.
\end{abstract}

\section{Keywords}

Financial Flexibility, Capital Structure, Investment and Financing, Credit Risk

\section{Introduction to Financial Flexibility}

Financial flexibility refers to the existence of variables and uncertainties in the operation of corporate capital and financial activities. Aiming at the changes in the environment of the company's financial activities and the uncertainty caused by the environment, the enterprise's dynamic implementation of financial management is the enterprise's flexible financial management (Tao, 2006). The study of "financial flexibility" can be traced back to the last century. Earlier, the focus of most scholars on financial flexibility was whether the cash flow was sufficient for companies to cope with special situations, and then gradually shifted to companies' response to uncertainty. Mingxu Liu (2014) believes in "Financial Flexibility Research" that financial flexibility allows companies to calmly deal with the adverse impact of uncertain environmental changes on companies and 
seize favorable investment opportunities in environmental changes. Based on this realistic background, corporate financial flexibility has been widely concerned and valued. Now people find that financial flexibility is not only a passive response in an uncertain environment, but also an active financial strategy.

From the perspective of capital flow, financial flexibility mainly involves the four aspects of financing, investment, operations and dividend distribution. In terms of financing, both the capital structure and the channels and methods of raising funds can have financial flexibility. Choosing the appropriate capital structure and financing channels is conducive to controlling the risk of debt service in a volatile environment. In terms of investment, whether it is a project investment or a financial investment, the amount of investment and the frequency of the investment often affect the company's use of funds and the financial flexibility of the company. In terms of operations, companies with different financial flexibilities will have different operating strategies: more inventories can reduce out-of-stock costs but will increase storage costs, reducing working capital and investing to obtain excess returns but may break the capital chain. Finally, in terms of dividend distribution, dividend distribution will reduce equity funds. Excessive dividend distribution will increase the external financing needs of enterprises. In the case of high financing constraints, enterprises may fall into difficulties due to insufficient financial flexibility.

Therefore, the importance of financial flexibility to the production and operation of enterprises is increasingly prominent. This article will introduce the impact of financial flexibility on enterprises and make suggestions on how to improve financial flexibility.

\section{The Impact of Financial Flexibility on Enterprises}

\subsection{Conservative Capital Structure Helps Companies Better Cope with Adverse Shocks}

In general, companies with high financial flexibility tend to have a more conservative capital structure. In the general period, this will increase the opportunity cost of the enterprise, but in the turbulent environment, it is likely to protect the enterprise from bankruptcy or merger fate. Obviously, when the economic environment is sluggish or even depressed, bad debts are the last thing that various financial institutions want to see, such as banks. Therefore, they will narrow the scope of loans, increase loan conditions, or recover loans in advance. For companies with more equity funds, this may limit their development speed, but it will not hurt the fundamentals. However, companies with high asset-liability ratios are different. The lack of debt funds is likely to cause the capital chain to break and eventually go bankrupt. Aimin Zeng, Yuanlue Peng, Lizhen Liang (2013) in "Why do companies prefer conservative capital structure?-An empirical evidence supporting financial flexibility theory" from the perspective of financial flexibility theory, with the global financial crisis that broke out in 2007 as an impact event, studied. The impact of the conservative 
capital structure maintained by enterprises before the financial crisis on their financial and investment behavior during the financial crisis. The empirical results found that prior to the financial crisis, conservative capital structure companies had higher net operating cash flow, but invested relatively less, thus maintaining higher cash balances and lower debt ratios, thus having greater financial flexibility and ability to continue financing in the future. During the financial crisis, companies with conservative capital structures exhibited stronger debt financing capabilities. Not only can they significantly increase investment expenditures, but their investment depends mainly on the investment opportunities they face in the crisis, and they are not sensitive to the availability of internal funds. On the contrary, the control group companies faced obvious financing constraints during the crisis, and it was difficult to raise the required funds by increasing liabilities, and their investment expenditures were more constrained by the net operating cash flow. Therefore, higher financial flexibility will bring a more conservative capital structure, thereby helping companies to cope with adverse shocks in an environment of great uncertainty.

\subsection{Increasing Financial Flexibility Will Help Reduce Credit Risk}

When an enterprise is unable to repay its due debts, then for creditors, credit risk exists. If the financial flexibility of the enterprise is low, the financial management strategy is more aggressive, and the use of higher financial leverage is preferred. Once the environment changes significantly, the enterprise cannot maintain normal operation and the credit risk is high. This is not just theoretical speculation. Zhaohui Xu, Zongfang Zhou (2014) in the article "The Mechanism of Financial Flexibility on Corporate Credit Risk under Financing Constraints" have found through empirical research that financial flexibility has a buffer effect on credit risk, and the greater the financing constraints, the more obvious the buffer effect. Correspondingly, the reduction of corporate credit risk is good news to reduce the difficulty of corporate loans, which is conducive to the continued operation of enterprises.

\subsection{Financial flexibility Helps Alleviate Underinvestment}

Man Wang, Nuo Xu, Minhao Tian (2016) by writing a related empirical research paper entitled "Financing Constraints, Financial Flexibility, and Underinvestment" shows that financial flexibility can alleviate the underinvestment of enterprises and increase the investment returns of enterprises. Although the financial flexibility reserve has weakened the investment strength of the enterprise to a certain extent, it has given the enterprise the opportunity to invest when it has the right opportunity. Opportunities for financial investment are often fleeting. Finding the right moment and making a decisive move can bring excess returns to the business in addition to daily operations. The project investment takes a long time and requires more funds. If there is a lack of financial flexibility reserves, it is likely that investment opportunities will be lost due to lack of funds. 
In addition, companies often have financing constraints, regardless of channel, method, or amount, and the greater the financing constraints, the greater the role of financial flexibility in alleviating underinvestment.

\subsection{Financial Flexibility Plays a Greater Role in Strategic Emerging Industries}

On the one hand, the increase of financial flexibility to the value of the enterprise is not a linear relationship, but an inverted " $U$ " shaped curve, that is, the role of financial flexibility on the value of the enterprise has a limit, and the limit will instead cause a decline in the value of the enterprise (Yao \& Chen, 2017). On the other hand, the effect of financial flexibility on enterprises is different in different types of enterprises. The impact of financial flexibility on enterprises is mainly reflected when the environmental uncertainty is large ( $\mathrm{Gu} \&$ Zhou, 2018). For traditional stable enterprises, the environmental changes are relatively small. The business of strategic emerging industries generally fluctuates greatly, so financial flexibility has the greatest and most obvious effect on such enterprises.

\section{How to Improve Corporate Financial Flexibility}

\subsection{Increase the Proportion of Equity Funds}

If a company has a high proportion of debt funds, it will face greater pressure on debt service, and high financial leverage will increase the company's financial risk. On the other hand, lenders tend to think that companies with higher asset-liability ratios have greater credit risk, so companies not only have more difficulty obtaining loans, but even if they get loans, creditors are likely to add many restrictive clauses in the contract to ensure funds Use or repayment. Therefore, to improve financial flexibility, it is necessary to appropriately increase the proportion of equity funds when making financing decisions, so that the capital structure is in a relatively safe range.

\subsection{Have More Capital Reserves}

Retaining more capital reserves is an important way to increase financial flexibility. In countless business cases, more and more people agree that "cash is king". First of all, the capital reserve can save the company from financial difficulties. Some companies, despite having a better strategic direction, even have a larger market, several rounds of financing, but once lack of financial support, the skyscraper collapsed. Secondly, the capital reserve is conducive to the investment and development of new products by enterprises. For many companies, innovation is the source of the company's development. However, many companies are not able to support the development of innovation with sufficient capital reserves and limit their development. Finally, capital reserves can save capital costs when financing constraints are large. The capital market is uncertain. When an enterprise has to raise funds at a higher cost, the existing capital reserves of the 
enterprise appear to be particularly important.

\subsection{Choose the Right Dividend Policy}

Dividend policy is the last and the most important part of the flow of funds. Long-term implementation of the zero dividend policy will inevitably cause dissatisfaction among shareholders, and long-term cash dividends may also be detrimental to corporate development. Choosing the right dividend policy and improving the financial flexibility of the enterprise will help prepare for the beginning of the next link in the last link of capital flow. Compared with cash dividend policies, stock repurchase programs may be more suitable for companies that need financial flexibility. On the one hand, dividend repurchases have tax incentives, and corporate repurchases of these shares can hedge stock options. On the other hand, stock repurchases will not change the stock price and will not cause the stock to fall. More importantly, stock repurchases are more flexible than rigid cash dividends, which can give companies a buffer when the business uncertainty is large.

\section{Conclusion and Deficiencies}

Financial flexibility has a significant impact on companies, especially strategic emerging companies. Sufficient financial flexibility reserves are an important means for enterprises to reduce financing costs, seize investment opportunities, and promote the sustainable and healthy development of enterprises. In addition, this article also puts forward suggestions on how to improve corporate financial reserves from different angles. However, most of the research references for this article are based on Chinese journals, and they have not been sorted and studied in foreign journals. To some extent, they may lack a certain international perspective. In the future, they will integrate domestic and foreign research on financial flexibility to improve.

\section{Conflicts of Interest}

The authors declare no conflicts of interest regarding the publication of this paper.

\section{References}

Gu, Y., \& Zhou, Q. G. (2018). Macroeconomic Uncertainty, Financing Environment Expectations and Corporate Leverage. Financial Review, No. 1, 11-28.

Liu, M. X. (2014). Research on Enterprise Financial Flexibility. Thesis. Chengdu: Southwestern University of Finance and Economics.

Tao, X. W. (2006). Enterprise Financial Flexibility and Flexible Financial Management. Accounting and Audit, No. 6, 273-274.

Wang, M., Xu, N., \& Tian, M. H. (2016). Financing constraints, financial flexibility and underinvestment. Research on Financial Issues, No. 9, 85-93.

Xu, Z. H., \& Zhou, Z. F. (2014). Mechanism of Financial Flexibility on Corporate Credit 
Risk under Financing Constraints. Technical Economy, No. 10, 106-112.

Yao, L. S., \& Chen, H. F. (2017). Does Financial Flexibility Reserve Increase Corporate Value?-Empirical Evidence from Companies Listed on GEM. East China Economic Management, No. 7, 139-143.

Zeng, A. M., Peng, Y. L., \& Liang, L. Z. (2013). Why Companies Prefer Conservative Capital Structure?-An Empirical Evidence Supporting Financial Flexibility Theory. Business Economics and Management, No. 6, 48-59. 